\title{
Can Analysts Really Forecast? Evidence from the Karachi Stock Exchange
}

\author{
Haris Bin Jamil, ${ }^{*}$ Aisha Ghazi Aurakzai, ${ }^{* *}$ and Muhammad \\ Subayyal $^{* * *}$
}

\begin{abstract}
This study examines the impact of analysts' recommendations on stock prices listed on the Karachi Stock Exchange for the period 2006-12. The recommendations are extracted from the daily Morning Shout report published by Khadim Ali Shah Bukhari Securities Ltd (KASB), which provides buy and sell recommendations for different stocks. We use the market model to estimate the abnormal returns around the recommendation dates for these securities. The study also investigates whether the abnormal returns are due to price pressure or information content. We find that investors earn abnormal returns on the basis of analysts' recommendations for these securities. The results are robust in considering only the sub-sample subsequent to 2008's global financial crisis, and are also consistent with the information content hypothesis and price pressure hypothesis.
\end{abstract}

Keywords: Analysts' recommendations, information content, price pressure, abnormal returns, market efficiency, Pakistan.

\section{JEL classification: G14, G24.}

\section{Introduction}

What gives an investor an advantage over others in the market? How does an inexperienced investor compete in a market filled with experts? The answer lies in the work of analysts who study the health of companies and make investment recommendations based on their performance. Brokerage firms invest millions of dollars employing qualified analysts to issue recommendations that are, in turn, published or sold to investors. Each recommendation is based on careful analysis and market surveys, given that the reputation of the analyst as well as the firm he/she represents is at stake. The question that arises is whether such recommendations really benefit investors in terms of excess returns.

\footnotetext{
* BBA student at FAST National University, Peshawar, Pakistan.

** BBA student at FAST National University, Peshawar, Pakistan.

**** PhD scholar and assistant professor at FAST National University, Peshawar, Pakistan.
} 
The impact of analysts' recommendations on stock prices has been clearly established in the literature. What is lacking, however, is relevant research on whether this impact emanates from the information contained in the recommendations or whether it is simply a result of price pressure. This forms the focus of our study. Additionally, we test the impact of information leaked prior to the publication of the recommendations. This will enable us to establish the form of market efficiency prevalent in the market under observation.

The market under observation is the Karachi Stock Exchange (KSE)_Pakistan's largest and most liquid stock exchange. The KSE serves the interest of individual as well as institutional investors, the trading community, and listed companies. Established in 1949, it now comprises four indices and 590 listed companies, and has a market capitalization of PRs 4.59 trillion. ${ }^{1}$ Authorized by the Securities and Exchange Commission of Pakistan (SECP), Khadim Ali Shah Bukhari (KASB) Securities is one of the country's largest pure agency brokerage firms and publishes its recommendations online in a daily web-post titled Morning Shout, with options to "buy," "sell," or "hold."

\section{Literature Review}

Cowles' (1933) study set in motion a vast body of research on the impact of analysts' recommendations. He concluded that such recommendations were not generally important to investors as they did not create any value. A wide range of studies followed, some denied the phenomenon while others agreed with it. Studies conducted by Bidwell (1977), Diefenbach (1972), and Logue and Tuttle (1973) on the role of security analysts supported Cowles' conclusion. His position was also strengthened by research conducted on investment managers by Jensen (1978), Fama (1991) and by Colker (1963).

Other researchers, however, have observed the existence of abnormal returns following such recommendations. Ball, Brown and Finn (1978) confirm that the analysts' recommendations lead to additional returns, but point out that these returns are greater during the months the recommendations are published. Once the publication is phased out, investors earn lower returns. They conclude that the share prices have a small impact on recommendations since the information provided is collected before publication.

\footnotetext{
${ }^{1}$ http://www.thenews.com.pk/Todays-News-3-173250-KSE-index-rises-on-institutional-buying (accessed 18 June 2013).
} 
Bjerring, Lakonishok and Vermaelen (1983) look at the recommendations issued by a leading Canadian brokerage firm and find that, after deducting transaction costs, the recommended securities show positive abnormal returns. Groth, Lewellen, Schlarbaum, and Lease (1979) reach a similar conclusion based on their study of the investment advice issued by a US brokerage house. Studying an entire set of the firm's recommendations for the period 1964-74, the authors conclude that returns tend to increase before, rather than after, a positive recommendation is issued. Elton, Gruber, and Grossman (1986) also note positive abnormal returns that remain in excess (3.43 percent) during the month of publication and two months after a change in brokerage recommendations. Downgraded recommendations, on the other hand, result in a 2.26 percent loss.

Copeland and Mayers (1982) conclude that the returns that result from analysts' recommendations are low, and the expected revenue is lower than the cost. According to Lynch (1989), analysts publish buy recommendations after a stock price rises, hence losing any investment opportunity. He attributes this to their preference for those stocks that attract the attention of institutional investors. Dorfman (1993) studies a set of recommendations concerning the 12 most popular shares on the NYSE; he shows that the price of nine shares fell in the 12 months after the recommendation date. Liu, Smith, and Syed (1990) also show that positive returns accrue nearer to the date the recommendations are issued.

Barber and Loeffler (1993) record abnormal returns of over 4 percent-nearly twice the amount calculated by previous studies. Their study is based on a column in the Wall Street Journal that compares analysts' recommendations with those of randomly selected securities via a "dartboard." The authors link these substantial excess returns to the high availability and circulation of the journal (which doubled between 1970/71 and 1988-90) compared to other methods used by previous studies. Higher circulation and availability mean that more investors have access to information in time, leading to greater demand for these securities. The study documents abnormal returns of -4.61 percent from day 2 through 25 $(t=-2.03)$. This mean reversion reflects the price pressure phenomenon, which is a result of the high visibility of information.

Whether recommendations have greater influence depends on their relation to the environment of the company being recommended. Recommendations are also temporarily affected by announced revised profits (Stickel, 1995). On the other hand, Walker and Hatfield (1996) find 
that investors do not earn significant profits by following analysts' recommendations. Womack (1996) finds that buy and sell recommendations can impinge on stock prices and influence these for weeks or months at a time.

Francis and Soffer (1997) introduce the qualitative aspect of trust, arguing that investors will not trust an analyst's recommendation, particularly if it is positive. However, they show that recommendations contain information, and that investors display more confidence in revised estimates, specifically when combined with favorable recommendations to buy or hold. Stickle (1995) reaches a similar conclusion regarding revised estimates.

Jaffe and Mahoney (1999) find that, even if recommendations do lead to excess returns, these are insignificant if one includes the cost of collecting information. Juergens (1999) argues that recommendations published together with an announcement of important information lead to significant additional returns. Moreover, investors tend to follow recommendations that are accompanied by basic economic data on the company in question (Ho \& Harris, 2000).

Some studies have focused on the stock exchange as a whole. Looking at the Australian stock exchange market over 1992-98, researchers observe that real estate agents' recommendations have had a significant impact on not only prices but also commercial activity-particularly on the date of publication. The impact is permanent for sell recommendations, but the buy side shows a temporary effect (Aitken et al., 2001).

Research on the London Stock Exchange comes to a similar conclusion regarding investors' profits, which increase with changes in recommendations. The impact on new "sell" recommendations is much stronger than on "buy" recommendations, which are rather weak (more so for smaller companies). Studies on the Asian market (Australia, Singapore, Korea, and Hong Kong) show that the latest recommendations affect share returns more so when given by reputed international financial companies (Lim \& Kim, 2004). Jegadeesh, Kim, Krische, and Lee (2004) argue that analysts neglect companies that are not known widely by focusing on "famous" shares.

Fang and Yasuda (2007) find that the analysts' recommendations do result in excess returns. Mokoaleli-Mokoteli (2005) reveal that investors react to changes in recommendations, with buy recommendations affecting investment decisions longer than sell recommendations. In a study on the 
G7 countries' stock exchanges, Jegadeesh and Kim (2006) find that sell recommendations are not as frequent as buy recommendations.

In 2000, the US Securities and Exchange Commission (SEC) issued Regulation Fair Disclosure (Reg FD), which denied legal access to any material information about a company before it was disclosed to the public. This was done because companies had been found revealing material nonpublic information before it was released to the public. It meant that analysts now had to use their own insight rather than rely on material nonpublic information. Goff and Keasler (2008) study the post-Reg FD recommendations for the S\&P 500, 600 and 400 indices, and conclude that upgrades are linked to positive abnormal returns while downgrades are associated with negative abnormal returns. Their study also reveals that recommendations that are accompanied by news lead to significantly larger reactions. Even those recommendations that are not accompanied by news, however, are significantly different from zero, implying that analysts' recommendations are informative per se.

Schlumpf, Schmid and Zimmermann's (2008) empirical study on buy recommendations are consistent with the notion that analysts' recommendations contain information that is quickly added to stock prices. Looking at the first and second release of information, the authors find that information is incorporated quickly following the first release. However, when the same information is released to a larger group of investors, the price change is not permanent. The study thus attributes the change in price on second release exclusively to price pressure.

Barber, Lehavy, and Trueman (2010) observe abnormal returns resulting from rating levels and rating changes. They show that recommendation upgrades based on the rating level earn the highest returns as opposed to downgrades, which show the lowest. When based on the sign and magnitude of a change in ratings, the more favorable the level of recommendation, the greater will be the return. The study also implies that a strategy based on both the recommendation level and change has the potential to outperform a strategy based exclusively on one or the other (5.2 compared to 3.5 basis points for a recommendation level-based strategy and 3.8 basis points for a recommendation change-based strategy). Interestingly, these levels and changes can be used to forecast future unexpected earnings as well as related market reactions.

Given that brokerage houses appear to spend a fortune on convincing investors to buy or sell certain securities, gives rise to an 
important question: What do these firms stand to gain? Grossman and Stiglitz (1980) make an interesting observation in stating that prices in the market cannot be based perfectly on all the available information because if this were true, then information seekers would be unable to earn any reward for their high-cost activities. Womack (1996) argues that the rational and competitive world seeks to compensate such costly activities with equivalent or higher-than-expected profits by underwriting the fees, profits, and commissions earned from trading securities. On the other side of the coin, investors should also be willing to pay only when the cost of obtaining such information is at least equal to the expected benefit.

We generally assume that the release of new earnings reports by companies is an important information resource for security recommendations, yet only 9 percent of new buy recommendations coincide with the issue of quarterly earnings reports. Womack (1996) observes that every calendar quarter of a firm equals approximately 63 trading days. This means that an earnings report date will fall 4.8 percent of the time as a matter of chance. Changes are thus not driven primarily by "information", or based on reactions to the latest market news or the release of earnings reports. What induces an analyst to recommend a security, is driven by "price," i.e., it relates to the price of the stock according to market and industry valuation models.

Holloway (1981) looks at strategies based on "value-line" recommendations (not taking any transaction costs into account), which can help achieve additional returns in relation to market value. Dimson and Marsh (1984) conclude that brokers are able to predict correctly the rise/fall of stock prices, but tend to exaggerate the extent of the variation: they may overestimate a rise and underestimate a fall.

In determining whether investor behavior is influenced by market behavior, DeBondt and Thaler (1985) find that investors who follow standard methods based on their experience tend to be overambitious or under-pessimistic with regard to winners or losers. This bias can cause deviations from the basic price level; hence, investors' decisions are affected by the near past. Finn (1988) studies the Australian stock market, and concludes that additional returns can be achieved within the first month of the publication of recommendations related to the market.

Subayyal and Shah (2011) are the first to test this phenomenon in Pakistan's context. They apply an event-study methodology to 277 recommendations taken from KASB's Morning Shout. The event window is 21 days long with a collection period of 141 days prior to the 
recommendation. The study finds evidence of abnormal returns: the cumulative abnormal return (CAR) on $t-8$ is 1.24 percent, indicating information content; the CAR on $t-9$ is 1.21 percent, implying that information was leaked prior to the announcement.

The evidence thus far suggests that analysts issue buy recommendations when the price is relatively low and sell recommendations when the price is relatively high: this is in accordance with traditional financial ratios.

Seyhun (1986) refers to the efficient market hypothesis (EMH) as the central focus of financial economics, supported by a large body of evidence beginning with Fama (1970). Although we are not concerned with determining the level of market efficiency, it is worth mentioning since our results will indirectly reflect the level of efficiency for the market in question. The EMH suggests that stock prices fully reflect all available information in the market. There is, however, a precondition for this extreme version of the hypothesis: the cost of ensuring that the price reflects the information on the security (information and trading cost) should always be zero (Grossman \& Stiglitz, 1980). A more economical, albeit weaker, form of this hypothesis states that security prices reflect information up to the point that the marginal benefit (expected profit) does not exceed the marginal cost (Jensen, 1978).

When the capital market is perfect, the stock's excess demand curves are seen to be perfectly elastic. This means that investors can sell or buy an unlimited amount of securities at a market price that reflects all the relevant information on that particular security. In the real world capital market, however, market inefficiencies will limit market forces from keeping the excess demand curves perfectly elastic. The following are alternatives to perfect capital markets.

The price pressure hypothesis states that prices will shift temporarily from their information-efficient values due to upward or downward pressure on the demand side. This implies that the demand curve for securities is not perfectly elastic. Temporary buying pressure on a recommended security by naïve investors will result in positive abnormal returns after a buy recommendation has been given as second-hand information.

Barber and Loeffler (1993) find evidence that is consistent with the price pressure hypothesis. Analysts' recommendations do result in significant abnormal returns, but these are reversed partially in the short 
term. Harris and Gruel (1986) argue that no new information on return distributions is conveyed when a firm is included in the S\&P 500 index, although they estimate abnormal returns of 3 percent for firms added to the index. They observe a complete price reversal over a two-week interval and interpret their results as supporting the price pressure hypothesis.

The information content hypothesis states that analysts' recommendations reveal relevant information on a security to the market, thereby resulting in abnormal returns that do not revert. The new information contained in the recommendation will result in a permanent price change as the market adjusts to the value of the new information.

Barber and Loeffler (1993) find evidence that is also consistent with the information hypothesis. Analysts' recommendations are seen as second-hand information in the market. The resulting abnormal returns are significant and do not fully revert in the short run. Trahan and Bolster (1995) relate the size of the firm to the information content hypothesis: analysts are likely to neglect smaller firms, which means that, as the firm's size decreases, its information content should increase in terms of published recommendations. This inverse relation leads to predictions regarding small firms being associated with larger abnormal returns.

\section{Data and Methodology}

This section describes our sample data and methodology.

\subsection{Sampling}

The study is divided into two parts: study A spans January 2006 to December 2012 and consists of 1,127 recommendations; study B spans January 2009 to December 2012 and includes 723 recommendations. This division allows us to check for any abnormalities that may have resulted from the crash that occurred in the KSE during the global financial crisis (August to December 2008) - the KSE witnessed an all-time low in June 2008. ${ }^{2}$ Hence, study B will exclude the impact of the financial crisis (an abnormal event) from the sample.

Our sampling method draws on other, similar studies. Analysts' buy recommendations are taken from the daily Morning Shout, which is published by KASB under license by the SECP. ${ }^{3}$ The post also provides in-

${ }^{2}$ http://www.geo.tv/6-21-2008/19613.htm (accessed 18 June 2013)

${ }^{3}$ http://www.kasb.com/securities/ (accessed 18 June 2013) 
depth coverage of 14 key listed sectors that account for 73 percent of the KSE 100 index. ${ }^{4}$ Although the post provides buy, sell, and hold recommendations, we focus solely on buy recommendations for a number of reasons. Short selling is forbidden by the KSE; 5 the ban is still in effect despite a plan to have it relaxed after February 2012,6 making it irrelevant for this study. Moreover, Barber et al. (2010) argue that buy recommendations have greater returns than sell recommendations, which analysts take into consideration when making recommendations.

\subsection{Event Study}

Our aim is to find which abnormal returns are attributable to the event in question. This is done by adjusting for returns that result from price fluctuations in the market as a whole. The event study assumes that the market information being processed about the event in question is unbiased as well as efficient. Event studies provide important information on the reaction of securities to a given event. In this manner, they can also help predict the reaction of securities to various events

\subsection{The Market Model}

We take 161 days' prices for each security to calculate the parameters of the market model. Of these, a 21-day period that spans 10 days before and after the event date $T=0$ is utilized as the event window to capture the effect of abnormal returns. We also take 141 days' share prices and market index data prior to the event window.

This brings the total number of observations to 362,894 for study A, i.e., 1,127 (recommended securities for the period) $x 161$ (the number of days under consideration) x 2 (security prices and market index). Similarly, study B includes 232,806 observations (723 x $161 \times 2)$. A two-tailed T-test is applied to check the significance of abnormal returns during the event window (21 days centered on the event date).

\subsection{Parameters}

We calculate a set of parameters to determine which abnormal returns occurred due to analysts' recommendations. First, the individual

\footnotetext{
${ }^{4}$ http://www.kasb.com/securities/equity_and_economic_research.aspx (accessed 18 June 2013)

${ }^{5}$ http://dailytimes.com.pk/default.asp?page=2006\%5C06\%5C24\%5Cstory_24-6-2006_pg5_11 (accessed 18 June 2013)

${ }^{6}$ http://dailytimes.com.pk/default.asp?page=2006\%5C06\%5C24\%5Cstory_24-6-2006_pg5_11 (accessed 18 June 2013)
} 
security returns suggested by analysts are calculated using the formula In(current security price)/In(previous security price). Next, the parameters $\left(\boldsymbol{\alpha}_{i}\right.$ and $\boldsymbol{\beta}_{i}$ ) are estimated to calculate abnormal returns.

A market model with linear parameters and linear variables is used to calculate the expected returns, using the following equation. All these parameters are used to calculate abnormal returns.

$$
R_{i t}=\alpha_{i}+\beta_{i} R_{m t}
$$

$R_{i t}$ is the expected return on security $i$ at time $t$. This equation is used just to calculate expected returns while we are interested in abnormal returns. Accordingly, rearranging equation (1), we get

$$
A R_{i t}=R_{i t}-\alpha_{i}-\beta_{i} R_{m t}
$$

Here, $A R_{i t}$ calculates the abnormal returns on security $i$ at time $t$. $\beta_{i}$ is the sensitivity of the stock return compared with changes in the market return $\left(R_{m t}\right)$ and is computed as

$$
\beta_{i}=\frac{\operatorname{cov}(\text { Rit }: R m t}{\operatorname{varRmt}}
$$

$\alpha_{i}$ is the excess estimated return. In the case of no abnormal returns, both sides of equation (3) will be equal:

$$
\alpha_{i}=R_{i t}-\beta_{i} R_{m t}
$$

\subsection{Research Hypotheses}

We present the following hypotheses:

- $\mathrm{H}_{0}$ : Analysts' recommendations have no impact on share prices.

- $\mathrm{H}_{\alpha}{ }^{1}$ : Analysts' recommendations have an impact on share prices.

- $\mathrm{H}_{\alpha}{ }^{2}$ : Analysts' recommendations have an impact on share prices due to price pressure.

- $\mathrm{H}_{\alpha}{ }^{3}$ : Analysts' recommendations have an impact on share prices due to information content.

- $\mathrm{H}_{\alpha}{ }^{4}$ : Analysts' recommendations have an impact on share prices due to information leaks. 


\section{Data Analysis and Discussion}

We compare the results for the period 2006-12 and 2009-12. The event window consists of 21 days and a simple t-test has been applied to test the statistical significance of the returns generated. The results reveal that analysts' recommendations do generate abnormal returns. The presence of information content is also tested and proves to be significant. The price pressure alternative, however, is refuted by the results.

\subsection{Analysis of Study A}

This analysis covers a period of seven years, from 2006 to 2012. Table 1 gives the results of the event window: on days $t-10, t-9, t-3, t-$ $2, t=0$, and $t+6$, the securities recommended by analysts earned statistically significant abnormal returns. These results are statistically different from zero at 10 percent and 5 percent significance levels.

On $t-10$ (ten days before the recommendations were published), the recommended securities earned 0.087 percent in abnormal returns on average. Similarly, on $t-9$ (nine days before the recommendations were published), the recommended securities earned 0.087 percent in abnormal returns on average. On day $t-3$, investors earned average abnormal returns of -0.011 percent. On day $t-2$, the recommended securities generated an average return of -0.018 percent. On the event day $t=0$ (the day the recommendations were published), the average abnormal returns were 0.014 percent. On day $t+6$ (six days after publication), the average investor earned abnormal returns of -0.096 percent.

As we can see, the average return becomes positive at 0.014 percent on the event day, implying that the analysts' recommendations did have an impact on security prices. We can also see that the average return becomes negative on day $t+6$, indicating the presence of price pressure. 
Table 1: Average abnormal returns on recommended securities (A)

\begin{tabular}{|c|c|c|c|c|c|c|}
\hline \multirow[b]{3}{*}{ Day } & \multirow[b]{3}{*}{ t-stat } & \multicolumn{3}{|r|}{ Test value $=0$} & \multirow{2}{*}{\multicolumn{2}{|c|}{$\begin{array}{l}\text { 95\% confidence interval of the } \\
\text { difference }\end{array}$}} \\
\hline & & \multirow[b]{2}{*}{ Df } & \multirow{2}{*}{$\begin{array}{l}\text { Sig. (2- } \\
\text { tailed) }\end{array}$} & \multirow{2}{*}{$\begin{array}{c}\text { Mean } \\
\text { difference }\end{array}$} & & \\
\hline & & & & & Lower & Upper \\
\hline$t-10$ & $1.616^{*}$ & 1126 & 0.106 & 0.000875684 & -0.00018725 & 0.00193862 \\
\hline$t-9$ & $1.533^{*}$ & 1126 & 0.126 & 0.000873083 & -0.00024467 & 0.00199084 \\
\hline $\mathrm{t}-8$ & -1.185 & 1126 & 0.236 & -0.000723098 & -0.00192069 & 0.00047449 \\
\hline $\mathrm{t}-7$ & 1.076 & 1126 & 0.282 & 0.000692639 & -0.00057079 & 0.00195607 \\
\hline$t-6$ & 0.690 & 1126 & 0.491 & 0.000393039 & -0.00072536 & 0.00151144 \\
\hline$t-5$ & -0.689 & 1126 & 0.491 & -0.000456385 & -0.00175613 & 0.00084336 \\
\hline $\mathrm{t}-4$ & 0.662 & 1125 & 0.508 & 0.000376977 & -0.00074009 & 0.00149404 \\
\hline$t-3$ & $-1.536^{*}$ & 1125 & 0.125 & -0.001106446 & -0.00252002 & 0.00030713 \\
\hline $\mathrm{t}-2$ & $-2.308^{* *}$ & 1126 & 0.021 & -0.001823887 & -0.00337410 & -0.00027368 \\
\hline $\mathrm{t}-1$ & 0.906 & 1126 & 0.365 & 0.000692608 & -0.00080683 & 0.00219205 \\
\hline to & $2.363^{* *}$ & 1126 & 0.018 & 0.001432665 & 0.00024307 & 0.00262226 \\
\hline$t+1$ & 1.051 & 1126 & 0.293 & 0.000794437 & -0.00068850 & 0.00227737 \\
\hline$t+2$ & 1.225 & 1126 & 0.221 & 0.000675698 & -0.00040658 & 0.00175797 \\
\hline$t+3$ & -0.747 & 1126 & 0.455 & -0.000455678 & -0.00165215 & 0.00074079 \\
\hline $\mathrm{t}+4$ & -1.155 & 1126 & 0.248 & -0.000612237 & -0.00165256 & 0.00042808 \\
\hline$t+5$ & 0.486 & 1126 & 0.627 & 0.000325313 & -0.00098831 & 0.00163893 \\
\hline$t+6$ & $-1.699^{*}$ & 1126 & 0.090 & -0.000964331 & -0.00207792 & 0.00014926 \\
\hline $\mathrm{t}+7$ & -0.827 & 1126 & 0.408 & -0.000734652 & -0.00247773 & 0.00100843 \\
\hline$t+8$ & -1.131 & 1126 & 0.258 & -0.000641325 & -0.00175409 & 0.00047144 \\
\hline$t+9$ & -0.287 & 1126 & 0.774 & -0.000199161 & -0.00156264 & 0.00116432 \\
\hline$t+10$ & -1.258 & 1126 & 0.209 & -0.001007210 & -0.00257809 & 0.00056367 \\
\hline
\end{tabular}

Note: Abnormal returns are calculated as actual returns minus expected returns (using the market model). ${ }^{*}{ }^{* *}$, and ${ }^{* * *}$ indicate $10 \%, 5 \%, \& 1 \%$ significance levels.

Source: Authors' calculations.

\subsection{Analysis of Study B}

Table 2 gives the results for the 2009-12 period. As mentioned earlier, the global financial crisis event is excluded from this segment. Instead, we focus on the post-crisis period. There are a total of 723 recommended securities with an event window of 21 days. Applying the ttest produces statistically significant abnormal returns for days $t-10, t-3$, $t-2, t=0, t+1, t+2, t+4$, and $t+10$.

Ten days before the recommendations were published $(t-10)$, the recommended securities generated average abnormal returns of 0.012 percent. The following day, $t-9$, the recommended securities earned 
investors an average abnormal return of -0.013 percent. On $t-2$, the average abnormal return was -0.026 percent. On the event day $t=0$, the day the recommendations were published, the recommended securities earned average abnormal returns of 0.016 percent. On day $t+1$, the day following publication, the recommended securities earned 0.016 percent in average abnormal returns. On day $t+2$, the average abnormal return was 0.015 percent. Four days after publication, on $t+4$, the average abnormal return was 0.013 percent. On $t+10$, the average abnormal return was 0.013 percent.

Table 2: Average abnormal returns on recommended securities (B)

\begin{tabular}{|c|c|c|c|c|c|c|}
\hline \multicolumn{7}{|c|}{ One-sample test } \\
\hline \multirow[b]{3}{*}{ Day } & \multicolumn{6}{|c|}{ Test value $=0$} \\
\hline & \multirow[b]{2}{*}{ t-stat } & \multirow[b]{2}{*}{ df } & \multirow{2}{*}{$\begin{array}{l}\text { Sig. }(2- \\
\text { tailed) }\end{array}$} & \multirow{2}{*}{$\begin{array}{c}\text { Mean } \\
\text { difference }\end{array}$} & \multicolumn{2}{|c|}{$\begin{array}{l}95 \% \text { confidence interval of the } \\
\text { difference }\end{array}$} \\
\hline & & & & & Lower & Upper \\
\hline$t-10$ & $1.848^{*}$ & 722 & 0.065 & 0.001276892 & -0.00007934 & 0.00263312 \\
\hline$t-9$ & 0.715 & 722 & 0.475 & 0.000542230 & -0.00094736 & 0.00203182 \\
\hline $\mathrm{t}-8$ & -0.255 & 722 & 0.799 & -0.000195172 & -0.00170011 & 0.00130977 \\
\hline $\mathrm{t}-7$ & 1.119 & 722 & 0.264 & 0.000809421 & -0.00061067 & 0.00222951 \\
\hline $\mathrm{t}-6$ & 0.578 & 722 & 0.563 & 0.000444884 & -0.00106614 & 0.00195591 \\
\hline$t-5$ & -0.432 & 722 & 0.666 & -0.000390013 & -0.00216081 & 0.00138078 \\
\hline $\mathrm{t}-4$ & 0.372 & 722 & 0.710 & 0.000275800 & -0.00118101 & 0.00173261 \\
\hline$t-3$ & $-1.342^{*}$ & 722 & 0.180 & -0.001337419 & -0.00329336 & 0.00061853 \\
\hline$t-2$ & $-2.398^{*}$ & 722 & 0.017 & -0.002658668 & -0.00483546 & -0.00048188 \\
\hline $\mathrm{t}-1$ & -0.458 & 722 & 0.647 & -0.000487513 & -0.00257517 & 0.00160014 \\
\hline t 0 & $2.132^{* *}$ & 722 & 0.033 & 0.001643838 & 0.00013032 & 0.00315735 \\
\hline$t+1$ & $2.535^{* *}$ & 722 & 0.011 & 0.001649561 & 0.00037198 & 0.00292714 \\
\hline$t+2$ & $2.502^{* *}$ & 722 & 0.013 & 0.001546085 & 0.00033315 & 0.00275902 \\
\hline$t+3$ & 0.180 & 722 & 0.857 & 0.000119709 & -0.00118358 & 0.00142300 \\
\hline $\mathrm{t}+4$ & $-1.916^{* *}$ & 722 & 0.056 & -0.001309458 & -0.00265090 & 0.00003198 \\
\hline$t+5$ & 0.689 & 722 & 0.491 & 0.000467363 & -0.00086343 & 0.00179816 \\
\hline$t+6$ & 0.254 & 722 & 0.800 & 0.000158450 & -0.00106786 & 0.00138476 \\
\hline $\mathrm{t}+7$ & -0.106 & 722 & 0.916 & -0.000132248 & -0.00258093 & 0.00231644 \\
\hline$t+8$ & -0.981 & 722 & 0.327 & -0.000696344 & -0.00209040 & 0.00069771 \\
\hline$t+9$ & -0.136 & 722 & 0.892 & -0.000091303 & -0.00140544 & 0.00122284 \\
\hline$t+10$ & $-1.603^{* *}$ & 722 & 0.109 & -0.001315979 & -0.00292797 & 0.00029601 \\
\hline
\end{tabular}

Note: Abnormal returns are calculated as actual returns minus expected returns (using the market model). ${ }^{*}{ }^{* *}$, and ${ }^{* *}$ indicate $10 \%, 5 \%, \& 1 \%$ significance levels.

Source: Authors' calculations. 
The CAR values in Table 3 reveal that there was no information leak prior to publication, as the average abnormal returns are negative. Subayyal and Shah (2011) investigate analysts' recommendations and show a CAR of 1.21 percent. We can conclude that the market no longer supports information leaks; even if a leak did occur, increased efficiency in the market cleared any arbitrage opportunity prior to the day the recommendations were issued.

Table 3: Statistically significant pre-announcement CAR for recommended KSE securities

\begin{tabular}{lcc}
\hline Day & & CAR \\
\hline $\mathrm{t}-10$ & 0.0012 & $0.12 \%$ \\
$\mathrm{t}-3$ & -0.0013 & $-0.01 \%$ \\
$\mathrm{t}-2$ & -0.0026 & $-0.27 \%$ \\
\hline
\end{tabular}

Source: Authors' calculations.

The CAR values in Table 4 increase up to day $t+2$ but then decrease due to the negative values for $t+4$ and $t+10$. This indicates an aspect of price pressure as the CAR has fallen by 26 percent by $t+10$. Since there is no complete mean reversion, we conclude that the recommendations incorporated some information content.

Table 4: Statistically significant post-announcement CAR for recommended KSE securities

\begin{tabular}{lcc}
\hline Day & & CAR \\
\hline $\mathrm{t}=0$ & 0.0016 & $0.16 \%$ \\
$\mathrm{t}+1$ & 0.0016 & $0.32 \%$ \\
$\mathrm{t}+2$ & 0.0015 & $0.47 \%$ \\
$\mathrm{t}+4$ & -0.0013 & $0.34 \%$ \\
$\mathrm{t}+10$ & -0.0013 & $0.21 \%$ \\
\hline
\end{tabular}

Source: Authors' calculations.

\section{Conclusion}

We have derived two types of results from this study: one incorporates the effects of the global financial crisis of 2008-an abnormal event-up to the event study (study A); the other covers the post-financial crisis period (study B). Both studies reject the null hypothesis and confirm that investor analyses do have an impact on security prices. However, the 
results of study A cannot be seen in isolation since the financial crisis had a significant impact on the market during this period. Thus, the stock prices do not exclusively portray the impact of analysts' recommendations.

For this reason, we focus more on study B, the results of which do not incorporate any abnormal events. As mentioned above, we have found that analysts' recommendations have a substantial impact on stock prices. These prices report significant abnormal returns on the day the recommendations were published, thus refuting the first alternative hypothesis. Moreover, the CAR display an increase followed by a decrease, implying significant partial mean reversion four and ten days after the event. The reversion reflects the impact of price pressure but as the mean does not revert completely, it shows that the recommendations had some information content. This refutes the second alternative hypothesis as well.

Since the analysts' recommendations contain information, the market undertakes an increase in prices. However, a sudden surge in demand moves prices well above their worth. Three days after the event, as the market fully absorbs the information, prices move back to their correct level. Investors seeking short-term profits should, therefore, sell their securities two days after the relevant recommendation is issued; longterm investors would benefit by waiting for the price pressure to ease on the fourth day to avoid losses to their capital investment.

Although previous studies conducted on the KSE market reveal the presence of information leaks (see Subayyal \& Shah, 2011), we find no evidence of such behavior in the pre-recommendation frame. The CAR are not positively significant before the event, implying that the market has largely incorporated and eliminated the effects of arbitrage. Investors can no longer take advantage of any such leak even if present. This shows that the market's degree of efficiency has improved, but is still not very strong, given the presence of price pressure and information content that affects the price of the securities. 


\section{References}

Barber, B. M., Lehavy, R., \& Trueman, B. (2010). Ratings changes, ratings levels, and the predictive value of analysts' recommendations. Financial Management, 39(2), 533-553.

Ball, R. (1978). Anomalies in relationships between securities' yields and yield-surrogates. Journal of Financial Economics, 6(2), 103-126.

Ball, R., Brown, P., \& Finn, F. J. (1978). Published investment recommendations and share prices: Are there free lunches in security analysis? JASSA, 2, 5-10.

Barber, B. M., \& Loeffler, D. (1993). The "dartboard" column: Secondhand information and price pressure. Journal of Financial and Quantitative Analysis, 28(2), 273-284.

Bidwell, C. M. (1977). How good is institutional brokerage research? Journal of Portfolio Management, 3(2), 26-31.

Bjerring, J. H., Lakonishok, J., \& Vermaelen, T. (1983). Stock prices and financial analysts' recommendations. Journal of Finance, 38(1), 187204.

Colker, S. (1963). An analysis of security recommendations by brokerage houses. Quarterly Review of Economics and Business, 3, 19-28.

Copeland, T., \& Mayers, D. (1982). The value line enigma (1965-1978): A case study of performance evaluation issues. Journal of Financial Economics, 10, 289-321.

Cowles, A. (1933). Can stock market forecasters forecast? Econometrica, 1(3), 309-324.

DeBondt, W. F., \& Thaler, R. (1985). Does the stock market overreact? Journal of Finance, 40(3), 793-805.

DeBondt, W. F., \& Thaler, R. H. (1990). Do security analysts overreact? American Economic Review, 80(2), 52-57.

Diefenbach, R. E. (1972). How good is institutional brokerage research? Financial Analysts Journal, 28(1), 54-60. 
Dimson, E., \& Marsh, P. (1984). An analysis of brokers' and analysts' unpublished forecasts of UK stock returns. Journal of Finance, 39(5), 1257-1292.

Elton, E. J., Gruber, M. J., \& Grossman, S. (1986). Discrete expectational data and portfolio performance. Journal of Finance, 41(3), 699-713.

Fama, E. (1970). Efficient capital markets: A review of theory and empirical work. Journal of Finance, 25(2), 383-417.

Fama, E. (1991). Efficient capital markets II. Journal of Finance, 46, 1575617.

Fang, L. H., \& Yasuda, A. (2007). Are stars' opinions worth more? The relation between analyst reputation and recommendation values (Working Paper No. 2007-12). Fontainebleau, France: INSEAD.

Francis, J., \& Soffer, L. (1997). The relative informativeness of analysts' stock recommendations and earnings forecast revisions. Journal of Accounting Research, 35(2), 193-211.

Goff, D., \& Keasler, T. (2008). Market reactions to analysts' initiations of coverage, post-Reg FD. Financial Decisions, 20(2), 1-18.

Grossman, S. J., \& Stiglitz, J. E. (1980). On the impossibility of informationally efficient markets. American Economic Review, 70(3), 393-408.

Groth, J. C., Lewellen, W. G., Schlarbaum, G. G., \& Lease, R. C. (1979). An analysis of brokerage house securities recommendations. Financial Analysts Journal, 35, 32-40.

Harris, L., \& Gruel, E. (1986). Price and volume effects associated with changes in the S\&P500 list: New evidence for the existence of price pressures. Journal of Finance, 41(4), 815-829.

Ho, M. J., \& Harris, R. S. (2000). Brokerage analysts' rationale for investment recommendations: Market responses to different types of information. Journal of Financial Research, 23(4), 449-468.

Holloway, C. (1981). A note on testing an aggressive investment strategy using value line ranks. Journal of Finance, 36, 711-719. 
Jaffe, J. F., \& Mahoney, J. M. (1999). The performance of investment newsletters. Journal of Financial Economics, 53(2), 289-307.

Jegadeesh, N., Kim, J., Krische, S., \& Lee, C. (2004). Analyzing the analysts: When do recommendations add value? Journal of Finance, $59,1083-1124$.

Jegadeesh, N., \& Kim, W. (2006). Value of analyst recommendations: International evidence. Journal of Financial Markets, 9(3), 274-309.

Jensen, M. (1978). Some anomalous evidence regarding market efficiency. Journal of Financial Economics, 6(2-3), 95-101.

Juergens, J. L. (1999). How do stock markets process analysts' recommendations? An intra-daily analysis (Working paper). Phoenix, AZ: Arizona State University.

Lim, K.-P., Brooks, R. D., \& Kim, J. H. (2008). Financial crisis and stock market efficiency: Empirical evidence from Asian countries. International Review of Financial Analysis, 17(3), 571-591.

Liu, P., Smith, S. D., \& Syed, A. A. (1990). Stock price reactions to the Wall Street Journal's securities recommendations. Journal of Financial and Quantitative Analysis, 25(3), 399-410.

Logue, D. E., \& Tuttle, D. L. (1973). Brokerage house investment advice. Financial Review, 8(1), 38-54.

Mokoaleli-Mokoteli, T. (2005). Are analysts biased? An analysis of analysts' stock recommendations for stocks that perform contrary to expectations. Unpublished $\mathrm{PhD}$ thesis. Cranfield University, Bedford, UK. Retrieved from https://dspace.lib.cranfield.ac.uk/bitstream/1826/ 934/2/mokoteli.pdf?origin=publication_detail

Schlumpf, P. M., Schmid, M. M., \& Zimmermann, H. (2008). The first- and second-hand effect of analysts' stock recommendations: Evidence from the Swiss stock market. European Financial Management, 14(5), 962-988.

Seyhun, H. N. (1986). Insiders' profits, costs of trading, and market efficiency. Journal of Financial Economics, 16(2), 189-212. 
Stickel, S. E. (1995). The anatomy of the performance of buy and sell recommendations. Financial Analysts Journal, 51(2), 25-39.

Subayyal, M., \& Shah, A. (2011). Impact of analysts' recommendations on stock prices: Evidence from the Karachi Stock Exchange (Mimeo). Retrieved from http:/ / saicon2011.ciitlahore.edu.pk/Economics/1216.pdf

Trahan, E. A., \& Bolster, P. J. (1995). The impact of Barron's recommendations on stock prices. Quarterly Journal of Business and Economics, 34, 3-15.

Walker, M. M., \& Hatfield, G. B. (1996). Professional stock analysts' recommendations: Implications for individual investors. Financial Services Review, 5(1), 13-29.

Womack, K. L. (1996). Do brokerage analysts' recommendations have investment value? Journal of Finance, 51(1), 137-167. 